RONG HU, Ph.D. ${ }^{1}$

(Corresponding author)

E-mail: hoorong@nuaa.edu.cn

JIALIN ZHU, M.S. ${ }^{1}$

E-mail: 1364302344@qq.com

JUNFENG ZHANG, Ph.D. ${ }^{1}$

E-mail: zhangjunfeng@nuaa.edu.cn

LIJUN ZHENG, M.S. ${ }^{1}$

E-mail: 1124989153@qq.com

BOWEN LIU, M.S. ${ }^{1}$

E-mail:1bw0530@163.com

${ }^{1}$ College of Civil Aviation

Nanjing University of Aeronautics and Astronautics

No.29, Jiangjun Avenue, Jiangning District, Nanjing,

Jiangsu Province, 211106, People's Republic of China
Traffic and Environment (Ecology) Original Scientific Paper Submitted: 2 June 2019 Accepted: 4 May 2020

\title{
CHARACTERISTICS AND MITIGATION MEASURES OF AIRCRAFT POLLUTANT EMISSIONS AT NANJING LUKOU INTERNATIONAL AIRPORT (NKG), CHINA
}

\section{ABSTRACT}

The assessment of local air pollution due to aircraft emissions at/near the airport is an important issue from the standpoint of environment and human health, but has not received due attention in China. In this paper, the pollutant emissions (i.e. HC, CO, NO,$S_{x}$ and PM) from aircraft during landing and take-off (LTO) cycles at Nanjing Lukou Airport (NKG) in 2016 were investigated using an improved method, which considered the taxi-in and-out time calculated based on the real data from the Civil Aviation Administration of China (CAAC), instead of using the referenced time recommended by ICAO. First, the pollutant emissions and their characteristics were studied from different perspectives. Second, two various mitigation measures of emissions were proposed, and the performance of emission reduction was analysed. Our analysis shows that: (1) A320 and B738 emitted the largest emissions at NKG; (2) pollutants were mainly emitted during the taxi mode, followed by climb mode; (3) B738 had the lowest emissions per (seat•LTO) among all aircraft, while CRJ had the lowest emissions per unit LTO; (4) shortening the taxiing time and upgrading aircraft engines are both effective measures to mitigate pollutant emissions.

\section{KEY WORDS}

air pollution; aircraft emissions; LTO method; pollutants; emission intensity;

\section{INTRODUCTION}

In recent years, air pollution has attracted an increasing concern within public opinion and scientific community in developing countries, just like what happened in the developed countries several decades ago. This is because of the known relationship between being surrounded by the polluted air and the increased adverse impact on human health $[1,2]$.

With the rapid growth in the aviation industry, pollutant emissions from the aviation sector increased by $98 \%$ from 1990 to 2006 [3]. They became an air pollution source that cannot be ignored. Some studies indicate that aircraft emissions can seriously affect the air quality [4-8], human health [2, 9], at airports and in communities around airports. It has been reported that for a modern twin-engine aircraft operating over an $800 \mathrm{~km}$ flight, about $25 \%$ of the total emissions are emitted during the landing and take-off (LTO) cycle [10]. Consequently, airports are suffering from enormous pressure to pay close attention to and reduce pollutant emissions.

Given this background, extensive research has been performed to discover types, amounts, and characteristics of pollutant emissions at/near airports [11-16]. There are several different approaches to measure and estimate pollutant emissions around airports [11, 17, 18]. An estimation approach was based on the total fuel consumption by aircraft, which uses fewer data [19]. Another approach, recommended in the China National Guide [20], was based on the total LTO number and the emission indices per LTO [16, 17, 21]. Considering the emission difference between engine thrust settings and aircraft types, the International Civil Aviation Organization (ICAO) promulgated the LTO 
cycle method [17]. As it provides a constant analytical frame of reference that allows the comparison of emissions calculation for different airports, the LTO cycle method is widely used to assess the pollutant emissions released by aircraft movements. A standard LTO cycle contains all aircraft operations at and near the airport below the altitude of $3,000 \mathrm{ft}$ (914 m) above field elevation. It includes four operation phases (approach, taxi, take-off, and climb), in terms of both aircraft engine thrust settings (expressed as a percentage of maximum rated thrust) and standard operating time in each specific operating mode (time-in-mode, TIM). Table 1 provides TIM and thrust setting for a standard LTO cycle.

Table 1 - TIM and thrust setting for a standard LTO cycle (ICAO, 2011)

\begin{tabular}{||c|c|c||}
\hline \hline Operating mode & TIM [min] & Thrust setting [\%] \\
\hline \hline Approach & 4.0 & 30 \\
\hline Taxi & 26.0 & 7 \\
\hline Take-off & 0.7 & 100 \\
\hline Climb & 2.2 & 85 \\
\hline
\end{tabular}

Though there are still some limitations in the usage of standard LTO cycles, e.g. classification of operating modes, emission indices, default thrust settings, and TIM [6, 22-25], the LTO cycle method has been used widely by different researchers and organizations around the world. In these studies, airports investigated were located in Europe [15, 26-29], Asia [13, 30-33], America [14, 34, 35], and Australia [8, $36,37]$. The pollutant emissions from aircraft operations at airport have been studied at a specific airport level $[27,35,38-40]$, on a regional multi-airport scale $[13,15,30]$, nationwide $[16,37,41,42]$, and also globally [9, 43-45]. These fruitful papers developed inventories of pollutant emissions at airports, helped people understand emissions better, and laid a solid foundation for the following studies.

Also, some studies have focused on emission reduction approaches and their benefits analysis, from an LTO cycle point of view. Taxi, one of LTO cycle operating modes, has the longest operation time. Consequently, taxiing aircraft are an essential source of pollutant emissions. A decrease of two minutes of taxiing time may result in a reduction of approximately $4-6 \%$ in the amount of LTO emissions or a decrease of approximately $7-8 \%$ in the amount of emissions in the taxiing mode $[15,27]$. At the same time, the aircraft taxiing speeds and taxiing routes have also impact on emissions [28]. Moreover, ambient meteorological conditions are also key factors of emission reduction. For example, the humidity has an obvious effect on pollutant emissions. For a fixed air-fuel ratio and ambient temperature, humidity affects $\mathrm{NO}_{\mathrm{x}}$ formation with a negative correlation [46-48]. And, as an aircraft operating at low engine thrust, e.g. taxiing and queuing, it has a significant portion of total pollutant emissions, APU and other handling equipment usage may serve as a valuable new approach to emission reduction [28, 39]. Also, flight procedure optimization is another effective measure to reduce fuel consumption and emissions, such as the Continuous Descent Approach (CDA) [49].

Furthermore, some recent studies have sought to do further research on different topics, using pollutant emissions data, which were calculated by the LTO cycle method. These issues include the relationships between pollutant emissions, local air quality, and human health and the factors that drive aircraft pollutant emissions, etc. [14, 29, 31, 50, 51].

In China, as one of the biggest aviation markets around the world, the pollutant emissions at airports are increasing rapidly and account for a larger portion in global amounts in the recent years [45]. Meanwhile, China seeks to build "greener" airports and aviation sector in the near future [52, 53]. However, the existing papers on pollutant emissions for China aviation are insufficient [33, 42, 54], especially for a specific airport with detailed analysis. The significance of this kind of research is uncontested from the viewpoint of air pollution, human health, emission reduction, and administration policies. In order to understand the extent to which the measure of emission reduction is required, it is necessary to investigate the inventory, level, and characteristics of pollutant emissions at/near the airport. Furthermore, as the taxi phase takes the largest share of operational time during the LTO cycle, accounting for $79.03 \%$, the uncertainty of the taxiing time could bring great deviation to the final assessment results of pollutant emissions. An estimation of aircraft pollutant emissions using an adjusted TIM for taxiing in China is lacking, to the best of our knowledge. In particular, previous studies usually focused on the adjustment of TIM for climb and approach $[31,33]$.

In light of this, the objectives of this paper are reported to: (i) develop a relatively accurate inventory of pollutant emissions $\left(\mathrm{HC}, \mathrm{CO}, \mathrm{NO}_{\mathrm{x}}, \mathrm{SO}_{\mathrm{x}}\right.$ and PM) from aircraft LTO operations based on the actual taxi-in and -out information of each flight and adjusted TIM, as well as fuel flows and emission 
indices revised by real meteorological parameters; (ii) grasp the distribution characteristics of pollutant emissions from four different views; (iii) investigate the emission reduction results of two different mitigation measures (shortening taxiing time and upgrading aircraft engines), at the Nanjing Lukou International Airport (NKG), China.

The remainder of this paper is organized as follows. Section 2 introduces the calculation methodology of aircraft pollutant emissions. Section 3 gives the research region and data sources. Section 4 presents the research results, including characteristics of aircraft pollutant emissions and performances of emission mitigation measures, and Section 5 draws the research conclusions.

\section{METHODOLOGY}

\subsection{Emission of pollutants}

In this paper, the LTO method is selected, which was recommended by ICAO to assess the pollutant emissions at NKG. This typical method is widely accepted and used. ICAO provides three different approaches: simple, advanced, and sophisticated techniques [17]. Each method has a degree of accuracy and an inverse degree of uncertainty, that is, the higher degree of accuracy and the lower degree of uncertainty. In this study, the advanced approach was accepted, according to the availability of data and information required.

In the advanced method, total emissions of pollutant $i\left(\mathrm{HC}, \mathrm{CO}, \mathrm{NO}_{\mathrm{x}}, \mathrm{SO}_{\mathrm{x}}\right)$ produced by aircraft $j$ for one LTO cycle (in grams), $E_{i j}$, are calculated by the following formula [17]:

$$
E_{i j}=\sum\left(T I M_{j k} \cdot 60\right) \cdot F F_{j k} \cdot E I_{i j k} \cdot N E_{j}
$$

where:

$$
\begin{aligned}
& T I M_{j k} \text { - time-in-mode } k \text { (approach, taxi, take-off, } \\
& \text { and climb) for aircraft } j[\mathrm{~min}] \text {; } \\
& F F_{j k} \quad \text { - fuel flow for mode } k \text { for each engine used } \\
& \text { on the aircraft } j[\mathrm{~kg} / \mathrm{s}] \text {; } \\
& E I_{i j k} \quad \text { - emission index for pollutant } i(\mathrm{HC}, \mathrm{CO} \text {, } \\
& \mathrm{NO}_{\mathrm{x}}, \mathrm{SO}_{\mathrm{x}} \text { ) in mode } k \text { for each engine } \\
& \text { used on aircraft } j \text { [g/kg fuel]; as ICAO } \\
& \text { does not provide standard approach for } \\
& \text { the calculation of } \mathrm{SO}_{\mathrm{x}} \text { emissions, an } \\
& \text { average } \mathrm{SO}_{\mathrm{x}} \text { emission index of } 1 \mathrm{~g} / \mathrm{kg} \text { fuel } \\
& \text { from the EPA's (Environmental Protection } \\
& \text { Agency) research was used. } \\
& N E_{j} \quad \text { - number of engines used on aircraft } j .
\end{aligned}
$$

Under the advanced approach, aircraft/engine combinations and the number of LTO cycle must be known first. The procedure for total pollutant emissions at a specific airport contains three steps as follows:

1) the pollutant emissions of a certain aircraft/engine combination per LTO cycle were calculated by previously stated formulas;

2) repeat step one, the emissions of each aircraft/ engine combination per LTO cycle can be calculated;

3) the total pollutant emissions could be obtained multiplying the individual emissions of each aircraft/engine combination per LTO cycle by the number of LTO cycle for the entire investigation period.

\subsection{Emission of particulate matter}

In this paper, the new First-order Approximation (FOA3.0) methodology was used to estimate the particulate matter (PM) emissions at the NKG [55]. The PM emissions produced by aircraft $j$ for one LTO cycle, $E(P M)_{j}$, can be calculated by the following formula:

$$
E(P M)_{j}=\sum\left(T I M M_{j k} \cdot 60\right) \cdot F F_{j k} \cdot E I(P M)_{j k} \cdot N E_{j}
$$

where $E I(P M)_{j k}$ is the emission index for PM in mode $k$ for each engine used on aircraft $j$ [g/kg fuel].

PM emissions include volatile and non-volatile emissions. Non-volatile PM exists at the engine exit plane while volatile PM nucleates as new particles or condenses on existing particles in the cooling exhaust plume [29, 55]. Currently, each component of PM must be calculated separately, with the total emission index being the sum of the parts [17]. Therefore, the emission index of PM can be calculated by the following formulas:

$$
\begin{aligned}
& E I(P M)=E I_{\text {vols }}+E I_{\text {nvols }} \\
& E I_{\text {vols }}=E I_{\text {vol-FSC }}+E I_{\text {vol-Fuelorganics }} \\
& E I_{\text {vol-FSC }}=\left(\frac{F S C \cdot \mathcal{E} \cdot M W_{\text {out }}}{M W_{s}}\right) \cdot 10^{3} \\
& E I_{\text {vol-Fuelorganics }}=\text { Non_S_component } \cdot \frac{E I_{H C(\text { Engine })}}{E I_{H C(C F M 56)}} \cdot 10^{-3} \\
& E I_{\text {vols }}=Q \cdot C I \cdot 10^{-3}
\end{aligned}
$$

If the smoke number $S N \leq 30$, best estimate:

$C I=0.0694 \cdot S N^{1.24}$

and upper bound: 
$C I=0.0012 \cdot S N^{2}+0.1312 \cdot S N+0.2255$

If $S N>30$, best estimate:

$C I=0.0297 \cdot S N^{2}-1.802 \cdot S N+31.94$

and upper bound:

$$
\begin{aligned}
& C I=0.0297 \cdot S N^{2}-1.6238 \cdot S N+26.801 \\
& Q=Q_{\text {core }} \text { or } Q_{\text {mixed }}
\end{aligned}
$$

If the engine type is turbofan:

$Q=Q_{\text {core }}=0.776 \cdot A F R+0.877$

If the engine type is internally mixed turbofan:

$Q=Q_{\text {mixed }}=0.776 \cdot A F R \cdot(1+\beta)+0.877$

where:
EI(PM) - emission index of PM (including volatile and non-volatile PM) [g/kg fuel];
$E I_{\text {vols }} \quad$ - emission index of the total of volatile $\mathrm{PM}[\mathrm{g} / \mathrm{kg}$ fuel];
$E I_{n v o l s} \quad$ - emission index of non-volatile PM [g/kg fuel];

FSC - fuel sulphur content (mass ratio with default 0.00068);

$E I_{\text {vol-FSC }}$ - volatile emission index attributable to $\mathrm{FSC}[\mathrm{g} / \mathrm{kg}$ fuel];

$E I_{\text {vol-FuelOrganics }}$ - volatile PM emission index of fuel organics [g/kg fuel];

$\varepsilon \quad-\mathrm{S}^{\mathrm{IV}}$ to $\mathrm{S}^{\mathrm{VI}}$ fractional conversion (default 0.033);

MWout $\quad-96$ (sulphate in the exhaust); $M W_{s} \quad-32\left(\mathrm{~S}^{\mathrm{IV}}\right.$ in fuel);

Non_S_component - a value derived from CFM56-2-C1 trends [mg/kg fuel];

$E I_{H C(C F M 56)}-$ mode-specific $\mathrm{HC}$ emission index for CFM56-2-C5 engine [ $\mathrm{g} / \mathrm{kg}$ fuel];

$E I_{H C \text { (Engine) }}$ - mode-specific $\mathrm{HC}$ emission index for the engine of concern $[\mathrm{g} / \mathrm{kg}$ fuel];

CI - concentration index $\left[\mathrm{mg} / \mathrm{m}^{3}\right]$;

SN $\quad-$ smoke number;

$Q \quad$ - core or mixed flow depending on engine test parameters during $S N$ measurements $\left[\mathrm{m}^{3} / \mathrm{kg}\right.$ fuel];

$Q_{\text {core }} \quad$ - core exhaust volumetric flow rate $\left[\mathrm{m}^{3} / \mathrm{kg}\right.$ fuel $]$;

$Q_{\text {mixed }} \quad$ - exhaust volumetric flow rate including core and bypass flow $\left[\mathrm{m}^{3} / \mathrm{kg}\right.$ fuel];

AFR - modal mass air-to-fuel ratio;

$\beta \quad-$ bypass ratio.

\subsection{Revision of fuel flow}

The LTO fuel flow of a specific engine has been given in the ICAO Aircraft Engine Emissions Databank [56]. However, the data are suitable for the International Standard Atmosphere (ISA) condition at sea level. If the airport meteorological conditions are not idealized, the fuel flow needs revision to fit the real conditions better.

The fuel flow in reference conditions (i.e. ISA condition at sea level with temperature $288.15 \mathrm{~K}$ and pressure $101.325 \mathrm{kPa}$ ) should be converted to the fuel flow in real conditions. The conversion formulas are as follows [37, 42]:

$$
\begin{aligned}
& F F=\frac{F F_{r e f} \delta_{a m b}}{\theta_{a m b}^{3.8} e^{0.2 M^{2}}} \\
& \theta_{a m b}=\frac{T_{a m b}+273.15}{288.15} \\
& \delta_{a m b}=\frac{P_{a m b}}{101.325}
\end{aligned}
$$

where:

$F F \quad$ - fuel flow in real conditions $[\mathrm{kg} / \mathrm{s}]$;

$F F_{\text {ref }}$ - fuel flow in reference conditions $[\mathrm{kg} / \mathrm{s}]$;

$\theta_{a m b}$ - temperature ratio of real conditions to reference conditions;

$\delta_{a m b}-$ pressure ratio of real conditions to reference conditions;

$M \quad$ - flight Mach number;

$T_{a m b}$ - ambient temperature in real conditions $\left[{ }^{\circ} \mathrm{C}\right]$;

$P_{a m b}$-ambient pressure in real conditions $[\mathrm{kPa}]$.

\subsection{Revision of emission indices of $\mathrm{HC}, \mathrm{CO}$, $\mathrm{NO}_{\mathrm{x}}$}

Similarly, the emission indices of $\mathrm{HC}, \mathrm{CO}$, and $\mathrm{NO}_{x}$, given in the ICAO Aircraft Engine Emissions Databank, also just fit the ISA condition at sea level. The emission indices are required to revise under real conditions.

For a clear distinction, emission indices for the ISA condition at sea level are called REIs (Reference Emission Indices), which are recommended by ICAO. In order to obtain the emission indices corresponding to different fuel flows under reference conditions, develop a log-log relationship between REIs and $F F_{r e f}$ The three species emission indices (i.e. $\mathrm{HC}, \mathrm{CO}$, and $\mathrm{NO}_{\mathrm{x}}$ ) and the corresponding fuel flow of each mode of LTO obtained from ICAO Aircraft Engine Emissions Databank are plotted on log-log scales, respectively. Take B738 equipped with CFM56-7B26 as an example: the regression fit of three species emission indices and fuel flow 

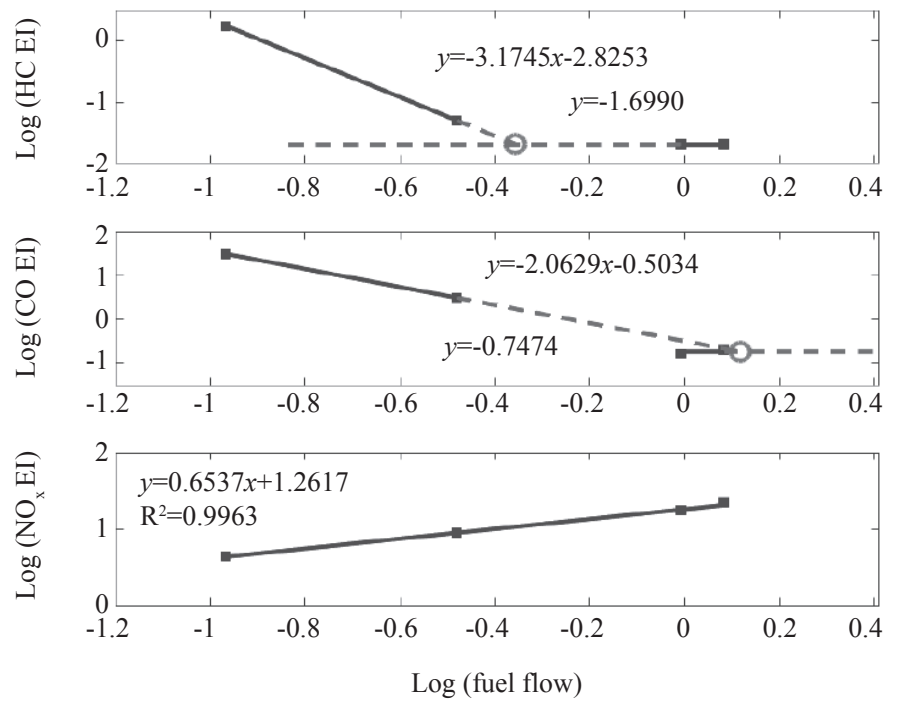

Figure 1-Log-log relationships between fuel flow and emission indices of $\mathrm{HC}, \mathrm{CO}$, and $\mathrm{NO}_{x}$ (CFM56-7B26)

are shown in Figure 1. It shows that the $\mathrm{HC}$ and $\mathrm{CO}$ are bi-linear regression fitted curves, and the $\mathrm{NO}_{\mathrm{x}}$ is curved by a point-to-point linear fit. Therefore, REIs of each pollutant could be obtained from a $\log$-log coordinate system corresponding to the $F F$ figured out in Section 2.3.

The REIs obtained by the above method fit the ISA condition at sea level. The REIs need converting to the real terms as follows $[42,57,58]$ :

$$
\begin{aligned}
& E I(H C)=\frac{R E I(H C) \theta_{a m b}^{3.3}}{\delta_{a m b}^{1.02}} \\
& E I(C O)=\frac{R E I(C O) \theta_{a m b}^{3.3}}{\delta_{a m b}^{1.02}} \\
& E I\left(N O_{x}\right)=R E I\left(N O_{x}\right) \exp (H)\left(\frac{\delta_{a m b}^{1.02}}{\theta_{a m b}^{3.3}}\right)^{\frac{1}{2}} \\
& H=-19.0 \cdot(\omega-0.0063)
\end{aligned}
$$

where:

$E I(H C), E I(C O), E I\left(N O_{x}\right)$ - emission indices of $\mathrm{HC}, \mathrm{CO}$, and $\mathrm{NO}_{\mathrm{x}}$ in real conditions $[\mathrm{g} / \mathrm{kg}$ fuel], respectively;

$H$ - humidity coefficient;

$\omega-$ specific humidity.

\subsection{Total pollutant emission}

Emissions of total pollutant $\left(\mathrm{HC}, \mathrm{CO}, \mathrm{NO}_{\mathrm{x}}, \mathrm{SO}_{\mathrm{x}}\right.$ and PM) for a particular aircraft $j$ in one LTO cycle can be calculated by the following formula:

$E_{j}\left(\mathrm{HC}, \mathrm{CO}, \mathrm{NO}_{\mathrm{x}}, \mathrm{SO}_{\mathrm{x}}, \mathrm{PM}\right)=$

$=\sum\left(T I M_{j k} \cdot 60\right) \cdot F F_{j k} \cdot E I_{j k}\left(\mathrm{HC}, \mathrm{CO}, \mathrm{NO}_{\mathrm{x}}, \mathrm{SO}_{\mathrm{x}}, \mathrm{PM}\right) \cdot N E_{j} \cdot 10^{-3}$

where:

$F F_{j k}$ - fuel flow in real conditions, for mode $k$ for each engine used on aircraft $j[\mathrm{~kg} / \mathrm{s}]$;
$E I_{j k}\left(\mathrm{HC}, \mathrm{CO}, \mathrm{NO}_{\mathrm{x}}, \mathrm{SO}_{\mathrm{x}}, \mathrm{PM}\right)-$ emission indices of $\mathrm{HC}, \mathrm{CO}, \mathrm{NO}_{\mathrm{x}}, \mathrm{SO}_{\mathrm{x}}$, and $\mathrm{PM}$, respectively in real conditions, in mode $k$ for each engine used on aircraft $j[\mathrm{~g} / \mathrm{kg}$ fuel].

Monthly pollutant emissions can be calculated by adding up the above emissions of all flights in one month. By adding up the emissions of each month, the annual pollutant emissions could be estimated.

\section{DATA SOURCES}

Nanjing Lukou International Airport was founded in 1997. The airport is located approximately 20 $\mathrm{km}$ south from the centre of the Nanjing city, Jiangsu province, China. With the rapid development in the past ten years (Figure 2), NKG has become one of the most important airports in the Yangtze River Delta, or even in China. The number of passengers and

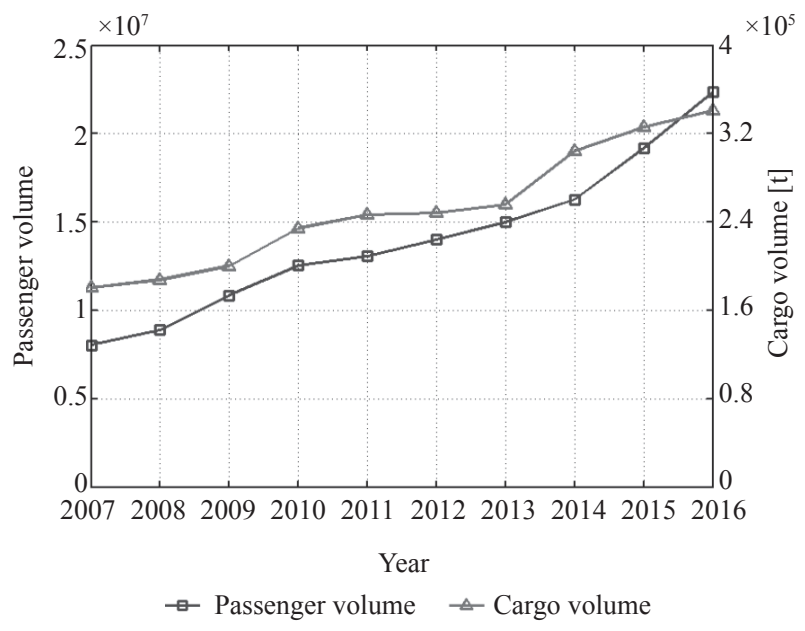

Figure 2 - The passenger and cargo volume at $N K G$ from 2007-2016 
freight carried were 22.4 million and 341.3 thousand tons in 2016, with an increase of $16.7 \%$ and $4.7 \%$, respectively, over the previous year. Facing a strong demand for air travel, NKG is expected to have a rapid growth in aircraft LTO cycles and pollutant emissions in the future. Meanwhile, excessive pollutant emissions and aircraft movements will inevitably cause a series of environmental problems around NKG $[59,60]$. Therefore, NKG has been taken as the research area for empirical analysis.

One focus of this paper is to produce an inventory of annual pollutant emissions during aircraft LTO cycles at NKG from January to December 2016. The flight schedules are taken from the airline schedules database (www.OAG.com) and an Operation Monitoring Center of Civil Aviation Administration of China (CAAC) airline on-time database. The operating carrier, flight number, aircraft type, origin airport, destination airport, and distance are given for each passenger and cargo flight. The flights have been sorted by time and flight number in order to avoid some miscalculations, such as flight double counting.

\section{Schedule database}

ICAO gives the standard value of TIM, which is shown in Table 1. However, considering the differences in airport layout, traffic congestion on the airfield, or operational rules of runways at a specific airport, the TIM varies from airport to airport, or even from flight to flight; and the default value of taxiing time has the most significant diversity [61].

To have a more precise estimation, the real taxiin and -out information was used from the CAAC airline on-time database to modify the default value of taxiing time. The real average taxiing time of each type of aircraft operated at NKG in 2016 is shown in Figure 3.

\section{Aircraft/engine combinations}

The engine type is a crucial factor in calculating the pollutant emissions. Aircraft/engine combinations are selected from the official websites of airlines and aircraft manufacturers. The detailed aircraft/engine

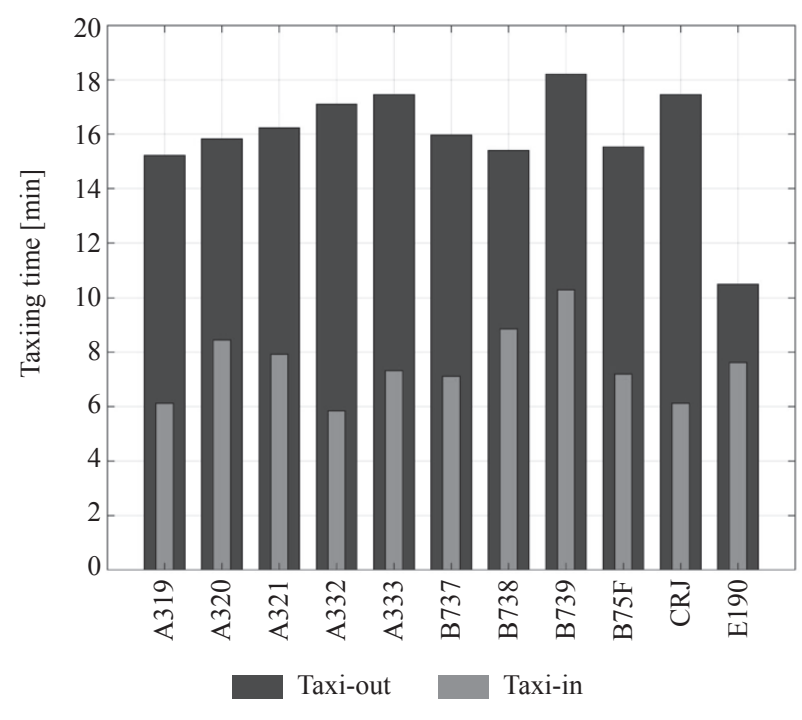

Figure 3 - The modified real average taxi-in and taxi-out time of each aircraft type

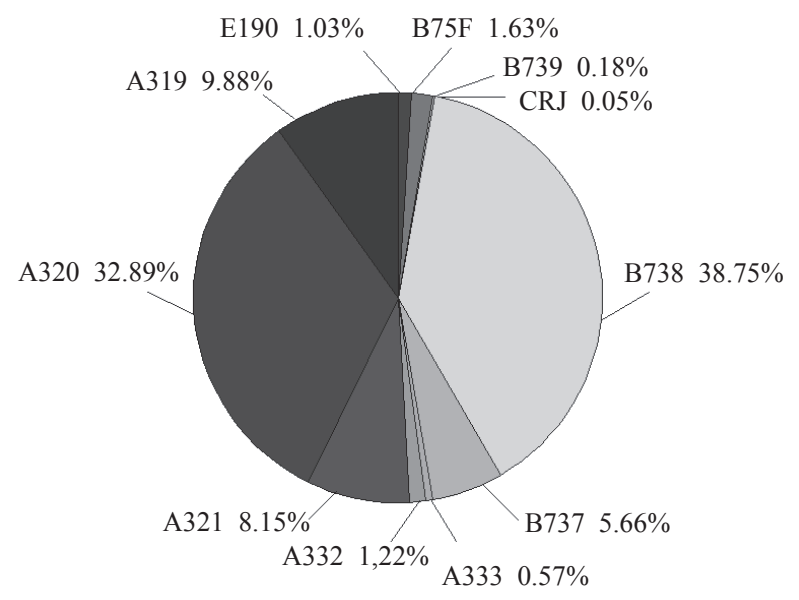

Figure 4 - Percentage of LTO cycles by aircraft category at NKG in 2016

combination information is too complicated and difficult to reckon. To simplify the analysis, the most typical combinations from the aircraft manufacturers and ICAO Aircraft Engine Emissions Databank were selected [56]. The distribution of aircraft operated at NKG in 2016 is shown in Figure 4. The combinations used for calculation in this paper are listed in Table 2.

Table 2 - Typical aircraft/engine combinations used for calculation

\begin{tabular}{|c|c|c|c||}
\hline Aircraft type & Engine type & Aircraft type & Engine type \\
\hline \hline A319 & CFM56-5B7-P & B737 & CFM56-7B22 \\
\hline A320 & CFM56-5B6 & B738 & CFM56-7B26 \\
\hline A321 & CFM56-5B3/3 & B739 & PW2037 \\
\hline A332 & Trent 772 & B75F & CF34-10E5 \\
\hline A333 & Trent 772 & E190 & \\
\hline CRJ & CF34-8C5 &
\end{tabular}




\section{Engine emission indices}

The ICAO Aircraft Engine Emissions Databank has $\mathrm{HC}, \mathrm{CO}$, and $\mathrm{NO}_{\mathrm{x}}$ emission indices and smoke number of different aircraft engine types. The engine emission indices are measured under the ISA condition at sea level. However, ICAO does not give referenced values of $\mathrm{SO}_{x}$ emission indices. The amount of $\mathrm{SO}_{\mathrm{x}}$ emission is directly related to the amount of sulphur in the fuel burned. In this study, the $\mathrm{SO}_{\mathrm{x}}$ emission index was set at $1 \mathrm{~g} / \mathrm{kg}$ - fuel, recommended by the EPA.

\section{RESULTS AND DISCUSSIONS}

The total pollutant emissions at Nanjing Lukou International Airport in 2016 were about 1,943.62 tons. The $\mathrm{CO}, \mathrm{NO}_{\mathrm{x}}$ were released in the highest quantities (totals were 1,019.34 and 766.70 tons, respectively), followed by $\mathrm{HC}$ (80.46 tons), $\mathrm{SO}_{\mathrm{x}}$ (71.27 tons), and PM (5.85 tons). The simple descriptive statistics in Table 3 gives an overview of all the used variables. The mean monthly number of LTO cycles was 7,180 during the 12-month observational period in 2016. The mean monthly fuel consumption was $5,939.19$ tons. The mean monthly values of $\mathrm{CO}$ and $\mathrm{NO}_{\mathrm{x}}$ were the highest of all pollutants (84.95 tons and 63.89 tons, respectively). The mean monthly value of $\mathrm{HC}$ was 6.71 tons, $\mathrm{SO}_{\mathrm{x}} 5.94$ tons, and PM 0.49 tons.

\subsection{Characteristics of aircraft pollutant emissions}

\section{Temporal distribution}

Figure 5 presents the estimated emissions of $\mathrm{HC}$, $\mathrm{CO}, \mathrm{NO}_{\mathrm{x}}, \mathrm{SO}_{\mathrm{x}}$, and $\mathrm{PM}$, monthly.

In July and August, the emissions of HC (7.32 and 7.84 tons), $\mathrm{CO}$ (95.02 and 100.34 tons), and PM ( 0.51 and 0.53 tons) were larger than in the other months in 2016. By contrast, in these months, the emissions of $\mathrm{NO}_{\mathrm{x}}$ and $\mathrm{SO}_{\mathrm{x}}$ were the lowest in 2016. In addition to factors like fuel consumption and the number of LTO cycles, the effect of meteorological parameters on emission indices may be another main reason for this trend. Aircraft engines could consume less fuel, and emit more $\mathrm{HC}, \mathrm{CO}$ and less $\mathrm{NO}_{\mathrm{x}}$ with the rise of ambient temperature and the descent of ambient pressure with the same other operation conditions (engine type, number of LTO cycles, etc.), which could be implied from the formulas in Section 2.4. The average temperature in July and August were $28.8,29.1^{\circ} \mathrm{C}$, which were higher than in January and December $\left(3.2\right.$ and $7.5^{\circ} \mathrm{C}$, respectively). Meanwhile, the average pressure in July and August was 1,001.1, 1,001.8 hPa, which were the lowest two months in 2016. The monthly variation trend of emission of $\mathrm{SO}_{\mathrm{x}}$ was the same as the variation of monthly fuel consumption due to the invariability of $\mathrm{SO}_{\mathrm{x}}$ emission index.
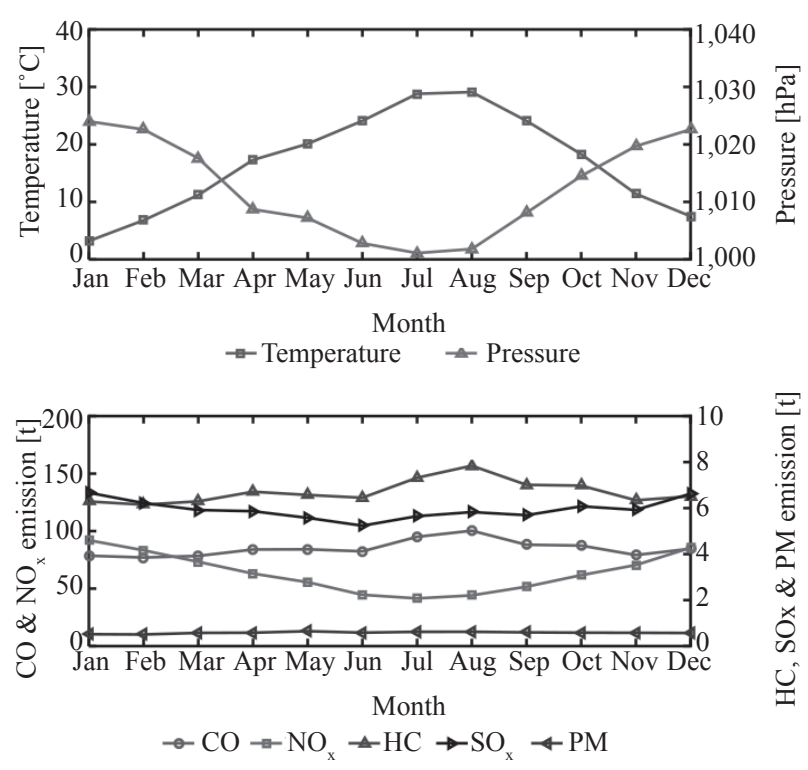

Figure 5 - Monthly variations in pollutant emissions and meteorological conditions

Table 3 -Descriptive statistics of all used variables in 2016

\begin{tabular}{||l|c|c|c|c|c||}
\hline & Minimum & Maximum & Mean & Std. deviation & Variance \\
\hline \hline LTO & 6,608 & 8,184 & 7,180 & 555.01 & $308,031.33$ \\
\hline Fuel $[\mathrm{t}]$ & $5,234.61$ & $6,667.94$ & $5,939.19$ & 414.76 & $172,023.06$ \\
\hline $\mathrm{HC}[\mathrm{t}]$ & 6.15 & 7.84 & 6.71 & 0.50 & 0.25 \\
\hline $\mathrm{CO}[\mathrm{t}]$ & 77.03 & 100.34 & 84.95 & 7.02 & 49.22 \\
\hline $\mathrm{NO}_{\mathrm{x}}[\mathrm{t}]$ & 41.46 & 92.01 & 63.89 & 17.21 & 296.12 \\
\hline $\mathrm{SO}_{\mathrm{x}}[\mathrm{t}]$ & 5.23 & 6.67 & 5.94 & 0.41 & 0.17 \\
\hline $\mathrm{PM}_{[\mathrm{t}}$ & 0.45 & 0.53 & 0.49 & 0.02 & 0.00 \\
\hline \hline
\end{tabular}




\section{Flight phase distribution}

The distribution of pollutant emissions for LTO operating modes is shown in Figure 6, including approach, taxi, take-off, and climb. On the whole, the taxi mode accounts for the most significant portion of total pollutant emissions at $53.48 \%$, followed by climb mode at $24.06 \%$, approach mode at $12.03 \%$, and take-off mode at $10.43 \%$, respectively.

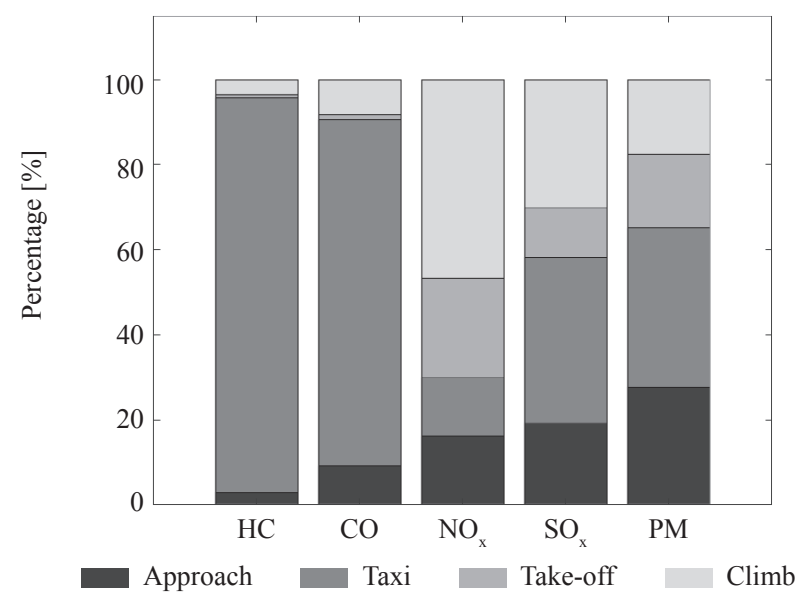

Figure 6-Distribution of pollutant emissions for each operating mode at NKG in 2016

On the other hand, Figure 6 shows that there are significant differences between different pollutant emissions in each flight phase. $\mathrm{HC}, \mathrm{CO}$, and $\mathrm{PM}$ are mainly emitted during the taxiing mode, accounting for $92.82 \%, 81.33 \%$, and $37.42 \%$, respectively, in the whole LTO cycle. As we know, the emission indices of $\mathrm{HC}$ and $\mathrm{CO}$ decrease with an increasing thrust, and taxiing mode has the longest operating time in the LTO cycle. Thus, in a working condition of lower thrust and longer time, the temperature and pressure of the engine combustion chamber are relatively low, which could lead to incomplete combustion of fuel and to an increase of $\mathrm{HC}$ and $\mathrm{CO}$ emissions. On the contrary, $\mathrm{CO}$ and $\mathrm{HC}$ emissions during take-off and climb modes account for $1.04 \%$, $1.26 \%$, respectively, in the whole LTO cycle.

$\mathrm{NO}_{\mathrm{x}}$ is mainly emitted during the climb mode, accounting for $46.74 \%$ in the LTO cycle, and the modes of approach, taxi, and take-off account for $16.04 \%, 13.78 \%$, and $23.44 \%$ in the LTO cycle, respectively. It has been discovered that the emission index of $\mathrm{NO}_{\mathrm{x}}$ is positively correlated to thrust setting $[29,56]$. As a sequence, the operating modes with high thrust setting, as take-off and climb, account for more $\mathrm{NO}_{\mathrm{x}}$ emission. This can also explain why TIM for take-off is only $0.7 \mathrm{~min}(2.13 \%$ of
TIM for a standard LTO cycle), while $\mathrm{NO}_{\mathrm{x}}$ emission accounts for as much as $23.44 \%$ in the whole LTO cycle.

The flight phase distribution of PM emission was more complex. The emission index of PM is relevant to smoke number and $\mathrm{HC}$ emission index. The value of the smoke number is positively related to thrust setting, while the $\mathrm{HC}$ emission index has a negative correlation with thrust setting. This makes PM emissions depend more on the operating time. Therefore, PM emissions account for $37.42 \%$ during the taxi mode.

The emission index of $\mathrm{SO}_{\mathrm{x}}$ is a constant, as $\mathrm{SO}_{\mathrm{x}}$ emission is proportional to fuel burn and depends on the fuel sulphur content. Thus, $\mathrm{SO}_{\mathrm{x}}$ emission during the approach, taxi, take-off, and climb modes account for $19.09 \%, 39.06 \%, 11.71 \%$, and $30.14 \%$, respectively.

\section{Aircraft type distribution}

Using the above emission calculation methods combined with flight schedules and aircraft/engine combination information, enables estimation of the annual total emissions of each pollutant released by various types of aircraft. The results sorted by quantity are illustrated in Figure 7. As seen in Figure 7, A320 produced about $40.47 \%$ of total LTO pollutant emissions (785.95 tons), which was larger than produced by any other type of aircraft, followed by B738 (615.52 tons).

The largest $\mathrm{NO}_{\mathrm{x}}, \mathrm{SO}_{\mathrm{x}}$ emissions were released by B738 (total 345.54 and 27.87 tons, respectively), followed by A320. This is because B738 operated

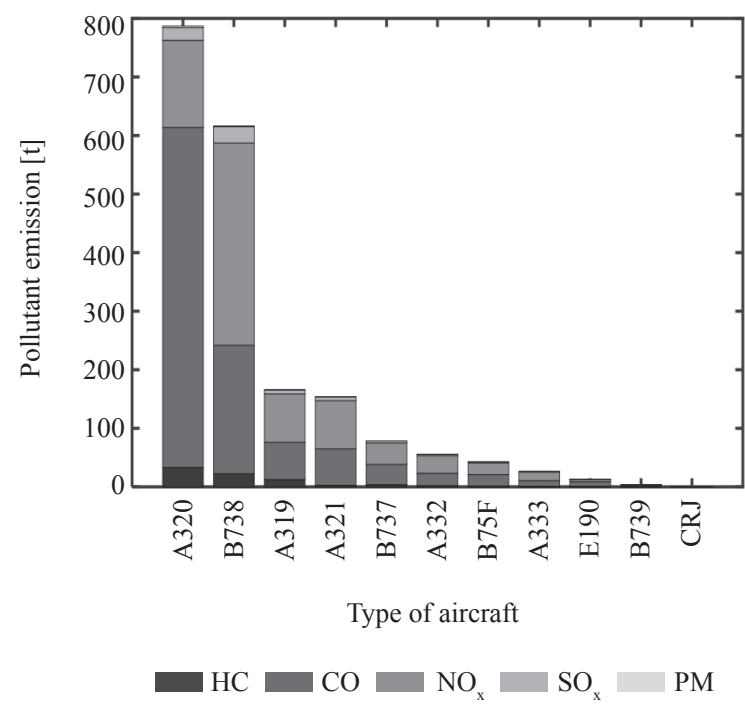

Figure 7 - Distribution of pollutant emissions from various types of aircraft at NKG in 2016 
the majority of LTO cycles at NKG (about $38.75 \%$ in the total LTO cycles). Moreover, the CO, HC and PM emissions of A320 were higher than B738, due to the difference of combustion efficiency between two engines of A320 and B738, even if the LTO cycles that operated by A320 were lower (about $32.89 \%$ in the total LTO cycles) than by B738.

\section{Emission intensity distribution}

The pollutant emission intensity $(\mathrm{kg} / \mathrm{LTO}$ or $\mathrm{kg} /($ seat $\bullet$ LTO)) is an index of pollutant emissions released per unit LTO or unit seat during one LTO cycle, which could be used to assess the pollutant emission efficiency of various types of aircraft. The results sorted by pollutant emission intensities are illustrated in Figure 8.

From an LTO-emission intensity point of view, CRJ is the most efficient type of aircraft, as CRJ is a small aircraft, about 90 seats, consuming less fuel during one LTO cycle. But from a seat-emission intensity point of view, B738 is the most efficient type of aircraft, followed by B737 and A321. From an environmental point of view, it would be a feasible approach of emission reduction to operating more aircraft with lower seat-emission intensity.

From the emission intensity point of view, inferences can be made about which type of aircraft has better performance at lower emissions. Aircraft emissions per unit LTO cycle, unit carrying capacity, and capacity utilization are likely to be more relevant considerations when choosing aircraft [36].

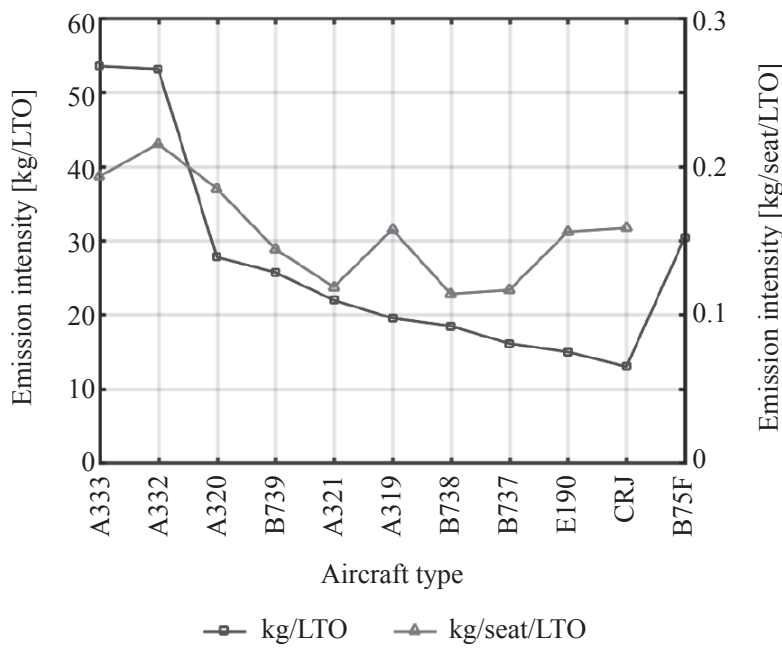

Figure 8 - Distribution of pollutant emissions intensity from various types of aircraft at $N K G$ in 2016

Note: The data of typical seating are selected from official websites of aircraft manufacturers. B75F was only used for cargo transportation.

\section{Uncertainty analysis}

However, these pollutant emissions are subject to some uncertainties as they are dependent on many factors. In this paper, there are two primary sources of uncertainties in the aircraft pollutant emission estimation. First, as the actual mixing height would change at different times [33], the difference of mixing layer height between the LTO cycle method and actual value will lead to uncertainty. Ambient temperatures have a dominant position in mixing layer height estimation $[33,62]$. The annual average temperature around NKG in 2016 was $16.8^{\circ} \mathrm{C}$ (http://data.cma.cn/) and very close to the default value of ISA. Therefore, we accepted the recommended values of mixing layer height in the LTO cycle method in this study. Secondly, the simplification of aircraft/engine combinations may be another source of uncertainty. The same type of aircraft may be equipped with different types of engines and vice versa. Taking B738 in Air China fleet operated at NKG as an example, most aircraft are equipped with the CFM56-7B26 engines, and only a few aircraft are equipped with CFM56-7B24 type. We made a calculation and found that there was less than a 5\% difference in total pollutant emissions between these two different engines during the same LTO operation. So, in this paper, we used the most typical combinations of aircraft/engine (listed in Table 2) for pollutant emission calculation.

\subsection{Mitigation measures of aircraft pollutant emissions}

A number of actions can be employed by airports, airlines, and other aviation operators to reduce aircraft pollutant emissions [28, 63-65]. These include shortening the taxiing time by optimizing ground taxi routes and operating the latest types of aircraft. The effects of these two measures on mitigating the aircraft pollutant emissions at NKG will be evaluated.

\section{Shortened taxiing time}

The taxi mode accounts for more than half of total pollutant emissions, at $53.48 \%$. However, taxiing is essential for an aircraft to access the terminals, the runways, and their home hangar or fixed based operators. Taxiing time varies from airport to airport, or even from day to day, from flight to flight at the same airport, due to the size and layout of the airfield area, traffic congestion on the ground, local meteorological conditions, etc. From an 
environmental point of view, the pollutant emissions during the taxi mode could be reduced by shortening the taxiing time.

To investigate the effect of taxiing time on pollutant emissions, a sensitivity analysis was conducted to evaluate the change of emissions for various durations of taxiing time. We set four different scenarios of taxiing time based on the current average taxiing time at NKG (as shown in Figure 3), (1) shortening by four minutes, (2) shortening by two minutes, (3) increasing by two minutes, and (4) increasing by four minutes.

The estimations show that the total pollutant emissions during taxi mode have an $8.85 \%$ reduction of total LTO emissions when taxiing time is shortened by 4 minutes at NKG. Even if there is only a decrease of 2 minutes in taxiing time, it could result in a decrease of about $4.43 \%$ total LTO emissions and a decrease of about $8.28 \%$ of pollutant emissions in the taxi mode. This is an exciting result of pollutant emission reduction. However, flight delay is a very serious, but a ubiquitous challenge at NKG; there were $43.32 \%$ of flights delayed at NKG in 2016. The congestion on the ground was a significant effect factor of the flight delay. When taxiing time increases by four minutes at NKG, there will be an $8.85 \%$ increase of total LTO emissions, especially $\mathrm{HC}$ emission will increase more than $15.44 \%$. Therefore, shortening the taxiing time is an effective measure to mitigate airport pollutant emissions at NKG (Figure 9).

The new terminal of NKG will be put into operation soon, and NKG will face more complex operating conditions with two runways and two terminals. Hence, the authority of NKG is expected to enhance cooperative scheduling of runways, terminals, and gates, to improve operating efficiency, shortening taxiing time, and reducing aircraft emissions.

\section{Upgraded aircraft engines}

The performance of aircraft engines also has an obvious effect on pollutant emissions. While the performance of engines was degraded due to long working hours and poor working conditions, fuel consumption and pollutant emissions increased. While aircraft are equipped with the latest types of engines using advanced design and manufacture technologies, the fuel consumption and pollutant emissions would be decreased, such as the A320neo equipped with LEAP-1A or PW1100G-JM offers efficiency with a $20 \%$ fuel burn reduction per seat

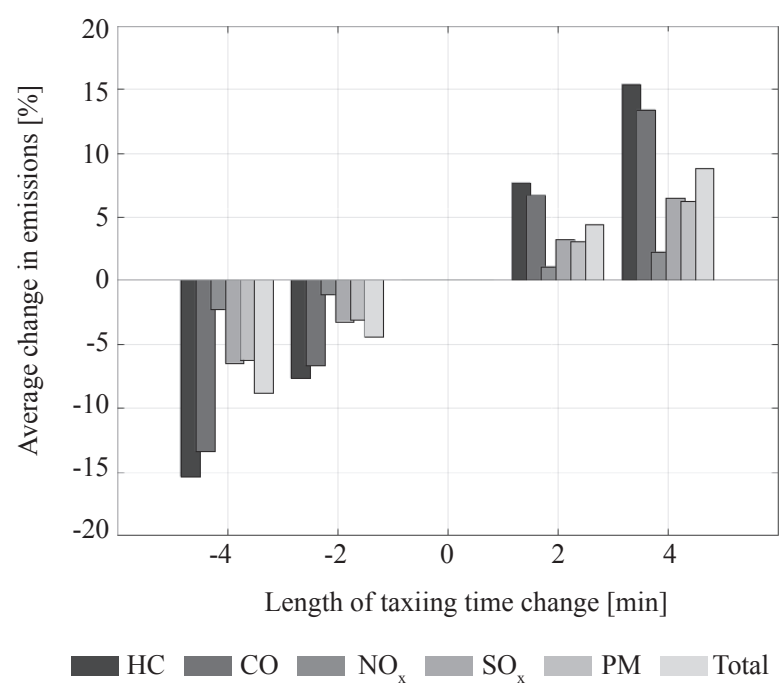

Figure 9 - Effect of shortening taxiing time on pollutant emissions at NKG in 2016

by 2020, and the A320neo's fuel savings translate into some 5,000 tons fewer $\mathrm{CO}_{2}$ emitted per aircraft annually [66].

There were 1,185 aircraft of the A320 family in operation in China, which was more than $40 \%$ of the whole Chinese fleet. If these aircraft were all replaced by the A320neo family, it would have considerable environmental benefits, at least. So, to investigate the effect of upgrading aircraft engines on pollutant emissions, a sensitivity analysis was conducted to evaluate the change of emissions for various replacement ratios, which were the percentages of the A320 family (equipped traditional CFM56-5B engines) operated at NKG in 2016, replaced by A320neo family (powered LEAP-1A engines). The replacement ratio varied from 0 percent to 100 percent. Figure 10 shows that an increase of $10 \%$ replacement ratio of A320neo family in A320 family results in a decrease of about $3.4 \%$ total LTO

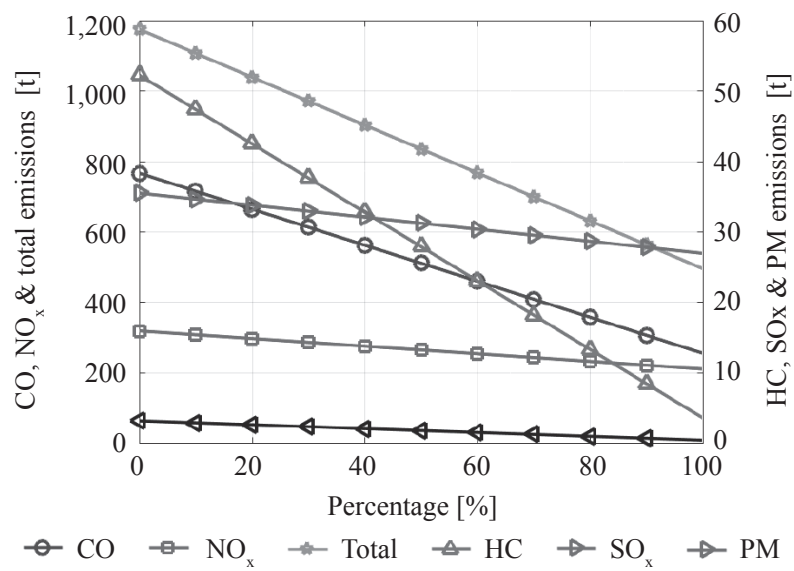

Figure 10 - Effect of upgrading aircraft engines on pollutant emissions of A320 family fleet at NKG 
$\mathrm{Hu}$ R, et al. Characteristics and Mitigation Measures of Aircraft Pollutant Emissions at Nanjing Lukou International Airport...

Table 4 - Emission indices of A320 and A320neo

\begin{tabular}{|c|c|c|c|c|c|}
\hline Index & Aircraft/Engine type & Approach & Taxi & Take-off & Climb \\
\hline \multirow{2}{*}{ Fuel flow $[\mathrm{kg} / \mathrm{sec}]$} & A320 family/CFM56-5B6 & 0.315 & 0.111 & 0.998 & 0.827 \\
\hline & A320neo family/LEAP-1A & 0.242 & 0.088 & 0.855 & 0.705 \\
\hline \multirow{2}{*}{$\mathrm{EI}$ of $\mathrm{HC}[\mathrm{g} / \mathrm{kg}]$} & A320 family/CFM56-5B6 & 0.2 & 3.4 & 0.1 & 0.2 \\
\hline & A320neo family/LEAP-1A & 0.04 & 0.28 & 0.02 & 0.02 \\
\hline \multirow{2}{*}{ EI of $\mathrm{CO}[\mathrm{g} / \mathrm{kg}]$} & A320 family/CFM56-5B6 & 17.75 & 46.1 & 4.48 & 12.18 \\
\hline & A320neo family/LEAP-1A & 2.74 & 21.4 & 0.22 & 0.27 \\
\hline \multirow{2}{*}{ EI of NOx $[\mathrm{g} / \mathrm{kg}]$} & A320 family/CFM56-5B6 & 10.32 & 3.9 & 13.51 & 10.41 \\
\hline & A320neo family/LEAP-1A & 8.67 & 4.63 & 18.77 & 11.16 \\
\hline \multirow{2}{*}{ EI of PM $[\mathrm{g} / \mathrm{kg}]$} & A320 family/CFM56-5B6 & 0.23 & 0.23 & 0.11 & 0.03 \\
\hline & A320neo family/LEAP-1A & 0.03 & 0.03 & 0.07 & 0.005 \\
\hline
\end{tabular}

pollutant emissions and a decrease of about 5.8\% pollutant emissions released by A320(neo) family. While all A320 family are replaced by the A320neo family, it will reduce about 680 tons of pollutant emissions in total, which is approximately $34.98 \%$ of total LTO pollutant emission at NKG in 2016. The decrease amount of $\mathrm{CO}$ emission is most significant in all pollutant emissions, about 511.69 tons when replacement ratio varied from $0 \%$ to $100 \%$; while the decrease proportion of $\mathrm{HC}$ emission is the highest in all pollutant emissions, the amount of $\mathrm{HC}$ emission at replacement ratio of $100 \%$, is only $6.77 \%$, of that the ratio is $0 \%$. The reason for this phenomenon is that the engines for the A320neo family have more efficient performance and release less emissions than engines for the A320 family (Table 4 shows the differences of engine performances between these two different types of engines). Therefore, using more aircraft equipped with the upgraded engines is also an effective, fast benefit measure to reduce pollutant emissions at airports.

\section{CONCLUSION}

In this study, the estimation of pollutant emissions ( $\mathrm{HC}, \mathrm{CO}, \mathrm{NO}_{\mathrm{x}} \mathrm{SO}_{\mathrm{x}}$, and $\mathrm{PM}$ ) of aircraft LTO cycles at Nanjing Lukou International Airport in 2016 is presented in great detail. The actual taxi-in and -out information of each flight and real meteorological data were used to have a more accurate adjusted TIM for taxiing and revised fuel flow and pollutant emission indices. The amount of pollutant emissions and its characteristics were analysed from four different viewpoints, and the emission reduction effects of two various mitigation measures, i.e., shortening the taxiing time and upgrading the aircraft engines, were also discussed in detail. The main conclusions are as follows:

1) The total aircraft pollutant emissions from LTO cycles at NKG in 2016 were $1,019.34$ tons CO, 766.70 tons $\mathrm{NO}_{\mathrm{x}}, 80.46$ tons $\mathrm{HC}, 71.27$ tons $\mathrm{SO}_{\mathrm{x}}$, and 5.85 tons $\mathrm{PM}$. The monthly variation of emissions is evident due to the airline schedule (i.e. the total number to LTO cycles) and meteorological conditions. In July and August, HC, $\mathrm{CO}$, and $\mathrm{PM}$ were the highest, while $\mathrm{NO}_{\mathrm{x}}$ was the lowest.

2) The taxi mode accounted for the most significant portion of total pollutant emissions at $53.48 \%$, due to the longest operating time. For $\mathrm{HC}, \mathrm{CO}$, and PM emissions, taxi mode was the major contributor. And, $\mathrm{NO}_{\mathrm{x}}$ was mainly emitted during the climb mode.

3) A320 was the maximum contributor among all aircraft types, followed by B738, due to their largest numbers of LTO cycles operated at NKG. From the seat-emission intensity distribution point of view, B738 is the most efficient type of aircraft, followed by B737 and A321. CRJ has the lowest emissions per unit LTO due to its smaller size.

4) Shortening the taxiing time is a feasible measure to mitigate the aircraft pollutant emissions. The results show that a decrease of 2 minutes in taxiing time caused a reduction of about $4.43 \%$ of total LTO pollutant emissions and a decrease of about $8.28 \%$ pollutant emissions in the taxi mode.

5) Upgrading aircraft engines also has a remarkable effect on emission reduction. If the aircraft fleet of A320 family operated at NKG in 2016 were 
all replaced by the A320neo family, it would reduce almost 680 tons of pollutant emissions, about $35 \%$ of total LTO pollutant emissions.

\section{ACKNOWLEDGMENT}

This work was supported by the Fundamental Research Funds for the Central Universities of China (Grant number NS2015068).

胡荣, 博士 ${ }^{1}$

E-mail: hoorong@nuaa.edu.cn

朱佳琳, 硕士 ${ }^{1}$

E-mail:1364302344@qq.com

张军峰, 博士 ${ }^{1}$

E-mail: zhangjunfeng@nuaa.edu.cn

郑丽君, 硕士 1

E-mail:1124989153@qq.com

刘博文, 硕士 ${ }^{1}$

E-mail: 1bw0530@163.com

1 南京航空航天大学, 民航学院

中国江苏省南京市江宁区将军大道29号, 211106

南京禄口国际机场飞机污染物排放特征及减排 措施

摘要

从环境和人类健康的角度来看, 评价机场附近 因飞机污染物排放造成的空气污染是一个重要的议 题, 但在中国尚未得到应有的重视。本文对南京禄 口机场 $(N K G)$ 2016年着陆和起飞 (LTO) 循环过 程中飞机的污染物排放 ( $H C 、 C O 、 N O_{x} 、 S O_{x}$ 和 $P M)$ 进行了研究, 根据中国民航局 $(C A A C)$ 的实 际数据计算滑入和滑出时间，而不是使用国际民航 组织建议的参考时间, 提出了一种改进的方法。首 先, 从不同角度研究了污染物排放及其特征。其 次, 提出了两种不同的减排措施, 并对减排效果进 行了分析。分析结果表明: (1) 南京禄口国际机场 $A 320$ 和 $B 738$ 污染物排放量最大; (2) 污染物排放 主要产生在滑行阶段, 其次是爬升阶段; (3) 在所 有飞机型号中, B738的每座位LTO排放量最低, $C R J$ 的每单位 $L T O$ 排放量最低; (4) 缩短滑行时间和升 级飞机发动机都能有效减少污染物的排放。

\section{关键词:}

空气污染；飞机排放；LTO方法；污染物；排放强度

\section{REFERENCES}

[1] Linn WS, Szlachcic Y, Henry G, et al. Air pollution and daily hospital admissions in Metropolitan Los Angeles. Environ Health Perspect. 2000;108: 427-434.

[2] Barrett SRH, Britter RE, Waitz IA. Global mortality attributable to aircraft cruise emissions. Environ Sci Technol. 2010;44: 7736-7742.

[3] ICAO. Environmental report 2010: Aviation and Climate Change. Montreal, Quebec, 2010.

[4] Unal A, Hu Y, Chang ME, et al. Airport related emissions and impacts on air quality: Application to the Atlanta International Airport. Atmos Environ. 2005;39: 5787-5798.

[5] Herndon SC, Jayne JT, Lobo P, et al. Commercial aircraft engine emissions characterization of in-use aircraft at Hartsfield-Jackson Atlanta International Airport. Environ Sci Technol. 2008;42: 1877-1883.

[6] Carslaw DC, Ropkins K, Laxen D, et al. Near-field commercial aircraft contribution to nitrogen oxides by engine, aircraft type, and airline by individual plume sampling. Environ Sci Technol. 2008;42: 1871-187.

[7] Dodson RE, Andres Houseman E, Morin B, et al. An analysis of continuous black carbon concentrations in proximity to an airport and major roadways. Atmos Environ. 2009;43: 3746-3773.

[8] Mazaheri M, Bostrom TE, Johnson GR, et al. Composition and morphology of particle emissions from in-use aircraft during takeoff and landing. Environ Sci Technol. 2013;47: 5235-5242.

[9] Yim SHL, Lee GL, Lee IH, et al. Global, regional and local health impacts of civil aviation emissions. Environ Res Lett. 2015;10: 034001.

[10] Saravanamuttoo HIH, Rogers GFC, Cohen H. Gas Turbine Theory ( $5^{\text {th }} \mathrm{Ed}$.); 2001.

[11] Kurniawan JS, Khardi S. Comparison of methodologies estimating emissions of aircraft pollutants, environmental impact assessment around airports. Environ Impact Assess Rev. 2011;31: 240-252.

[12] Grampella M, Lo PL, Martini G, et al. The impact of technology progress on aviation noise and emissions. Transp Res Part A Policy Pract. 2017;103: 525-540.

[13] Song S, Shon Z. Emissions of greenhouse gases and air pollutants from commercial aircraft at international airports in Korea. Atmos Environ. 2012;61: 148-158.

[14] Vujović D, Todorović N. An assessment of pollutant emissions due to air traffic at Nikola Tesla International Airport, Belgrade, and the link between local air quality and weather types. Transp Res Part D Transp Environ. 2017;56: 85-94.

[15] Kesgin U. Aircraft emissions at Turkish airports. Energy. 2006;31: 372-384.

[16] Bo X, Xue X, Xu J, et al. Aviation's emissions and contribution to the air quality in China. Atmos Environ. 2019;201: 121-131.

[17] ICAO. Airport Air Qualitye Manual Doc 9889; 2011.

[18] Masiol M, Harrison RM. Aircraft engine exhaust emissions and other airport-related contributions to ambient air pollution: A review. Atmos Environ. 2014;95: 409-455.

[19] EEA. EMEP/EEA air pollutant emission inventory guidebook. Available from: https://www.eea.europa.eu/publications/emep-eea-guidebook-2016 [Accessed 6 March 2020].

[20] MEE. Technical guide for compiling air pollutant emission inventory of nonroad moving sources. Beijing; 2014.

[21] Lu C, Liu H, Song D, et al. The Establishment of LTO Emission Inventory of Civil Aviation Airports Based on Big Data. IOP Conf Ser Earth Environ Sci. 2018;128: 012069.

[22] Nikoleris T, Gupta G, Kistler M. Detailed estimation of fuel consumption and emissions during aircraft taxi operations at Dallas/Fort Worth International Airport. Transp Res Part D Transp Environ. 2011;16: 302-308. 
[23] Khadilkar H, Balakrishnan H. Estimation of aircraft taxi fuel burn using flight data recorder archives. Transp Res Part D Transp Environ. 2012;17: 532-537.

[24] Herndon SC, Wood EC, Northway MJ, et al. Aircraft Hydrocarbon Emissions at Oakland International Airport. Environ Sci Technol. 2009;43: 1730-1736.

[25] Wood EC, Herndon SC, Timko MT, et al. Speciation and Chemical Evolution of Nitrogen Oxides in Aircraft Exhaust near Airports. Environ Sci Technol. 2008;42: 18841891.

[26] Simonetti I, Maltagliati S, Manfrida G. Air quality impact of a middle size airport within an urban context through EDMS simulation. Transp Res Part D Transp Environ. 2015;40: 144-154.

[27] Y1lmaz İ. Emissions from passenger aircrafts at Kayseri Airport, Turkey. J Air Transp Manag. 2017;58: 176-182.

[28] Winther M, Kousgaard U, Oxbøl A. Calculation of odour emissions from aircraft engines at Copenhagen Airport. Sci Total Environ; 2006;366: 218-232.

[29] Stettler MEJ, Eastham S, Barrett SRH. Air quality and public health impacts of UK airports. Part I: Emissions. Atmos Environ. 2011;45: 5415-5424.

[30] Taghizadeh SA, Shafabakhsh GH, Aghayan I. Evaluation of aircraft emission at Imam Khomeini International Airport and Mehrabad International Airport. Int $J$ Environ Sci Technol. 2019;16: 6587-6598.

[31] Yang X, Cheng S, Lang J, et al. Characterization of aircraft emissions and air quality impacts of an international airport. J Environ Sci (China). 2018;72: 198-207.

[32] Chilongola FD, Ahyudanari E. Aviation and Aircraft Engine Emissions at Juanda International Airport. In: IOP Conference Series: Materials Science and Engineering; 2019. Available from: doi:10.1088/1757$899 \mathrm{X} / 645 / 1 / 012022$

[33] Zhou Y, Jiao Y, Lang J, et al. Improved estimation of air pollutant emissions from landing and takeoff cycles of civil aircraft in China. Environ Pollut. 2019;249: 463-471.

[34] Ashok A, Balakrishnan H, Barrett SRH. Reducing the air quality and CO2climate impacts of taxi and takeoff operations at airports. Transp Res Part D Transp Environ. 2017;54: 287-303.

[35] Graver BM, Frey HC. Estimation of air carrier emissions at Raleigh-Durham international airport. In: Proceedings of the Air and Waste Management Association's Annual Conference and Exhibition, AWMA; 2009. p. 2502-2516.

[36] Mazaheri M, Johnson GR, Morawska L. An inventory of particle and gaseous emissions from large aircraft thrust engine operations at an airport. Atmos Environ. 2011;45: 3500-3507.

[37] Pham V Van, Tang J, Alam S, et al. Aviation emission inventory development and analysis. Environ Model Softw. 2010;25: 1738-1753.

[38] Carslaw DC, Beevers SD, Ropkins K, et al. Detecting and quantifying aircraft and other on-airport contributions to ambient nitrogen oxides in the vicinity of a large international airport. Atmos Environ. 2006;40: 5424-5434.

[39] Winther M, Kousgaard U, Ellermann T, et al. Emissions of $\mathrm{NO}_{\mathrm{x}}$, particle mass and particle numbers from aircraft main engines, APU's and handling equipment at Copenhagen Airport. Atmos Environ. 2015;100: 218-229.

[40] Mokalled T, Le Calvé S, Badaro-Saliba N, et al. Identi- fying the impact of Beirut Airport's activities on local air quality - Part I: Emissions inventory of NO2and VOCs. Atmos Environ. 2018;187: 435-444.

[41] Song S, Shon Z. National Emissions of Greenhouse Gases and Air Pollutants from Commercial Aircraft in the Troposphere over South Korea. Terr Atmos Ocean Sci. 2014;25: 61-76.

[42] Fan W, Sun Y, Zhu T, et al. Emissions of $\mathrm{HC}, \mathrm{CO}, \mathrm{NO}_{\mathrm{x}}$, $\mathrm{CO} 2$, and $\mathrm{SO} 2$ from civil aviation in China in 2010. Atmos Environ. 2012;56: 52-57.

[43] Kim BY, Fleming GG, Lee JJ, et al. System for assessing Aviation's Global Emissions (SAGE), Part 1: Model description and inventory results. Transp Res Part D Transp Environ. 2007;12: 325-346.

[44] Simone NW, Stettler MEJ, Barrett SRH. Rapid estimation of global civil aviation emissions with uncertainty quantification. Transp Res Part D Transp Environ. 2013;25: 33-41.

[45] Wilkerson JT, Jacobson MZ, Malwitz A, et al. Analysis of emission data from global commercial aviation: 2004 and 2006. Atmos Chem Phys. 2010;10: 6391-6408.

[46] Turgut ET, Usanmaz O. An assessment of cruise $\mathrm{NO}_{\mathrm{x}}$ emissions of short-haul commercial flights. Atmos Environ. 2017;171: 191-204.

[47] Kauffman CW, Subramanian AK, Rogers DW, et al. Ambient Effects on Idling Gas Turbine Emissions. J Aircr. 1981;18: 15-22.

[48] EPA. Alternative control techniques document- $-\mathrm{NO}_{x}$ emissions from Stationary Gas Turbines (No. EPA453/R-93-007). North Carolina; 1993.

[49] Novak D, Bucak T, Radišić T. Development, design and flight test evaluation of continuous descent approach procedure in FIR Zagreb. Promet - Traffic Transp. 2009;21: 319-329.

[50] Xu C, Zhu J, Hu R. Index decomposition of airport carbon emission factors in Jiangsu province based on Log mean divasia index. Aeronaut Comput Tech. 2018;48: 86-90.

[51] Kuzu SL. Estimation and dispersion modeling of landing and take-off (LTO) cycle emissions from Atatürk International Airport. Air Qual Atmos Heal. 2018;11: 153-161.

[52] CAAC. The $13^{\text {th }}$ Five-Year Plan of Energy Conservation and Emissions Reduction in Civil Aviation Sector. Available from: http://www.caac.gov.cn/XXGK/XXGK/ZCFBJD/201702/t20170228_42798.html [Accessed 6 March 2020].

[53] CAAC. Action Plan for the Construction of Fourtype Airport (2020-2035). Available from: http:// www.caac.gov.cn/XXGK/XXGK/ZCFB/202001/ P020200110664548555485.pdf [Accessed 6 March 2020].

[54] Ma J, Zhou X. Development of a three-dimensional inventory of aircraft $\mathrm{NO}_{\mathrm{x}}$ emissions over China. Atmos Environ. 2000;34: 389-396.

[55] Wayson RL, Fleming GG, Iovinelli R. Methodology to estimate particulate matter emissions from certified commercial aircraft engines. $J$ Air Waste Manag Assoc. 2009;59: 91-100.

[56] EASA. ICAO Aircraft Engine Emissions Databank. Available from: https://www.easa.europa.eu/easa-andyou/environment/icao-aircraft-engine-emissions-databank [Accessed 9 December 2018]. 
[57] SAE. AIR 5715:Procedure for the Calculation of Aircraft Emissions. New York; 2009.

[58] Chen D, Hu M, Han K, et al. Short/medium-term prediction for the aviation emissions in the en route airspace considering the fluctuation in air traffic demand. Transp Res Part D Transp Environ. 2016;48: 46-62.

[59] People. Nanjing Lukou Airport was shut down due to fog and haze. Available from: http://js.people.com.cn/ $\mathrm{html} / 2013 / 12 / 07 / 273712 . \mathrm{html}$ [Accessed 6 March 2020].

[60] Environmental Protection Bureau of Nanjing. List of petitioners (No.12). Available from: http://hbj.nanjing.gov. cn/zthg/zyhjbhdchtk/dczg/201806/t20180623_446942. html [Accessed 28 May 2019].

[61] Chati YS, Balakrishnan H. Analysis of Aircraft Fuel Burn and Emissions in the Landing and Take Off Cycle using Operational Data. In: $6^{\text {th }}$ International Conference on Research in Air Transportation; 2014.
[62] Cheng SY, Jin YQ, Liu L, et al. Estimation of atmospheric mixing heights over large areas using data from airport meteorological stations. J Environ Sci Heal Part A. 2002;37: 991-1007.

[63] Neuling U, Kaltschmitt M. Techno-economic and environmental analysis of aviation biofuels. Fuel Process Technol. 2018;171: 54-69.

[64] Turgut ET, Cavcar M, Usanmaz O, et al. Investigating actual landing and takeoff operations for time-in-mode, fuel and emissions parameters on domestic routes in Turkey. Transp Res Part D Transp Environ. 2017;53: 249-262.

[65] Lulić Z, Mavrin I, Mahalec I. Aspects of Using Biological Regenerative Fuels in Internal Combustion Engines. Promet - Traffic Transp. 1998;10: 75-78.

[66] Airbus. A320neo. Available from: https://www.airbus. com/aircraft/passenger-aircraft/a320-family/a320neo. html [Accessed 6 March 2020]. 